\title{
Quantifying urban physical growth types in Banda Aceh City after the 2004 Indian Ocean Tsunami
}

\author{
Ikhwan Amri and Sri Rum Giyarsih* \\ Department of Environmental Geography, Faculty of Geography, Universitas Gadjah Mada, Indonesia
}

\begin{abstract}
Banda Aceh was the most affected city by the 2004 Indian Ocean Tsunami. This city has grown rapidly because of disaster recovery activities. Therefore, this study aims to identify the types of urban physical growth in Banda Aceh City quantitatively from 2005 to 2019. The characteristics of growth were identified by integrating geographic information systems and remote sensing. The analysis showed that the main types of urban physical growth in the city were edge-expansion in 2005-2009 and infilling in 20092019. The percentage of spontaneous growth area was the lowest in both periods. The process of reconstruction and rehabilitation was considered to greatly affect the types of urban physical growth, where newly built-up areas were established close to the existing built-up areas. This also caused urban densification in a relatively short time. The process of urbanization had reached a stable stage in the city so that the surrounding suburbs have the potential to experience regional transformation. Overall, the approach used in this study resulted in a more objective understanding of identifying the urban physical growth characteristics for better urban planning.
\end{abstract}

\section{Introduction}

Urban growth is a spatial and demographic process and refers to the increased importance of towns and cities as a concentration of population within a particular economy and society [1]. Urban growth is one of the important issues that are being discussed at this time in urban studies. It is related to the increasing number of people living in urban areas. United Nations estimated that $55.3 \%$ of the world's population lives in urban settlements in 2018 [2]. One aspect that is often examined in urban growth is physical morphology through monitoring the multi-temporal built-up areas.

Urban physical growth consists of three types, namely infilling, edge-expansion, and spontaneous growth [3]. Infilling is characterized by the increase of new built-up area around the existing built-up area and leading inward so that urban areas become more compact. Edge-expansion (edge-extension or urban fringe development) is a type of growth characterized by the addition of a new built-up area on the edges of the existing built-up area. Spontaneous growth (outlying or leapfrog development) is characterized by the emergence of a new built-up area that is far from the existing built-up area. The latter pattern is further classified into 3 types: isolated, linear, and clustered growth. Analysis of urban physical growth types has been widely studied in big cities under normal growth conditions, for example in Nanjing, China [4]; Guangzhou, China [5]; Hanoi, Vietnam [6], Addis Ababa, Ethiopia [7], and so on. Such research is rarely carried out in cities after a shock event occurs, such as natural disasters.
The city of Banda Aceh experienced a tsunami disaster on December 26, 2004, known as the 2004 Indian Ocean Tsunami (IOT). The National Geophysical Data Center/World Data Service noted that the tsunami was triggered by an earthquake $(9.1 \mathrm{Mw})$ with a depth of $30 \mathrm{~km}$ and its epicenter located at $3.3^{\circ}$ North Latitude and 95.8 East Longitude [8]. The tsunami flow reached inland as far as 3 to $4 \mathrm{~km}$ from the coastline in Banda Aceh City [9]. Badan Nasional Penanggulangan Bencana (National Disaster Management Agency/BNPB) reported that the natural disaster resulted in 165,791 lives lost and missing, 2,830 people were injured, 50,970 people were affected and displaced, 179,312 housing units were severely damaged, and 3,148 health, worship, and education facilities were damaged in Aceh Province [10]. Most of these losses were found in Banda Aceh City, where the population density was the highest in Aceh Province.

The urban physical development process was the top priority for disaster recovery in the short term [11]. The reconstruction and rehabilitation process took place during 2005-2009 and was coordinated by Badan Rekonstruksi dan Rehabilitasi (Rehabilitation and Reconstruction Agency/BRR). Urban physical growth at that time was expected to take place quickly along with the high demand for redevelopment. In 2009, the work period of BRR ended and a new spatial planning regulation (qanun) was put in place, namely Qanun No. 4/2009 about the Regional Spatial Plan of Banda Aceh City 2009-2029.

An analysis of the types of urban physical growth in the Banda Aceh City had previously been carried out by Achmad et al. during 2005-2009 [12]. They estimated

* Corresponding author: srirum@ugm.ac.id 
the growth pattern of the city to be dominated by the edge-expansion category at that time, but the analysis was still limited to qualitative techniques. Using a different model, this study tries to identify the type of urban physical growth in a quantitative manner, i.e. area percentage, so the results become more objective. On the other hand, the study of urban physical growth in the city of Banda Aceh needs to be carried out further as a consideration in future urban planning. Therefore, the main objective of this research is to identify the types of urban physical growth quantitatively in Banda Aceh City during 2005-2009 and 2009-2019. The first period relates to the process of reconstruction and rehabilitation after the 2004 IOT or urban recovery, while the last is the post-urban recovery period.

\section{Research method}

\subsection{Study area}

This research was conducted in the city of Banda Aceh, Aceh Province, Indonesia. The city consists of 9 subdistricts (kecamatan). It is geographically bordered by Aceh Besar District in the south and east, the Strait of Malacca in the north, and the Indian Ocean in the west (Figure. 1). The area of this city is $55.6 \mathrm{~km}^{2}$. It has an average elevation of 0.8 meters above sea level and a relatively flat slope. The total population in 2019 was 270,321 [13]. The position of the city is directly adjacent to the subduction zone so that the level of vulnerability to earthquake and tsunami disasters is relatively high.

Banda Aceh has long been the governmental and economic center in the province of Aceh. Thus, the process of urban development in this city was more intensive compared to other regions in Aceh Province. However, the 2004 IOT damaged more than half of the city that was built a long time ago within a short time span, mainly in coastal areas. Therefore, Banda Aceh City was chosen as a location for post-disaster urban physical growth research.

\subsection{Data and built-up area extraction}

This study used various remote sensing data for the analysis of urban physical growth. Three medium resolution images were used to detect land cover changes: Landsat 5 TM for 2005 and 2009, and Landsat 8 OLI/TIRS for 2019 (Table 1). Landsat images were obtained from the United States Geological Survey (USGS) website. The images were downloaded with cloud cover criteria of less than $10 \%$ so that the data obtained is more accurate for land cover classification.

Table 1. Description of Landsat images used for the research.

\begin{tabular}{|c|c|c|c|}
\hline $\begin{array}{c}\text { Acquisition } \\
\text { Date }\end{array}$ & Path/Row & $\begin{array}{c}\text { Satellite } \\
\text { Images }\end{array}$ & $\begin{array}{c}\text { Spatial } \\
\text { Resolution }\end{array}$ \\
\hline $06 / 01 / 2005$ & $131 / 56$ & Landsat $5 \mathrm{TM}$ & $30 \mathrm{~m}$ \\
\hline $10 / 06 / 2009$ & $131 / 56$ & Landsat $5 \mathrm{TM}$ & $30 \mathrm{~m}$ \\
\hline $21 / 05 / 2019$ & $131 / 56$ & $\begin{array}{c}\text { Landsat } 8 \\
\text { OLI/TIRS }\end{array}$ & $30 \mathrm{~m}$ \\
\hline
\end{tabular}

The Landsat images had been corrected geometrically and radiometrically. In this study, the land cover was classified into 2 classes, i.e. built-up area and non-built-up area, using the supervised classification method with maximum likelihood algorithm. This method has been widely used to extract built-up data in various studies with satisfactory results. It classifies land cover based on input from the operator (region of

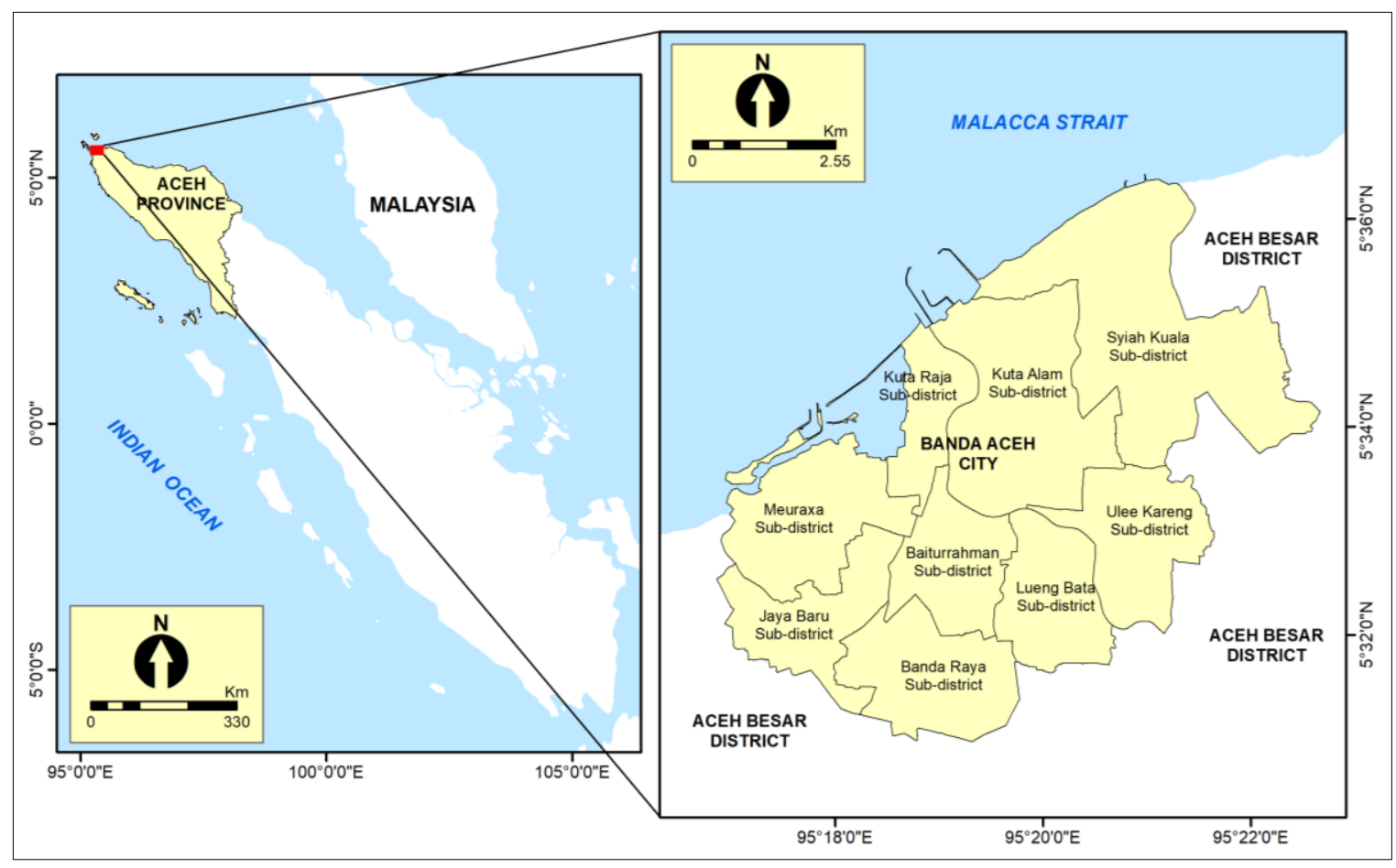

Fig. 1. Map of study area. 
interest/ROI) and bases the probability of occurrence of a class with statistical assumptions for each class in each normally distributed band [14]. The images processing were carried out using ENVI 5.3 software. The making of ROI in this research was carried out using Google Earth and high-resolution imagery obtained from Badan Perencanaan Pembangunan Daerah (Regional Development Planning Agency/Bappeda) of Banda Aceh City. Local knowledge of the study area aided the researchers in making ROI. The classified images were edited manually to improve accuracy.

Accuracy assessment was done by utilizing the same data source as making ROI as reference data. The method used for accuracy assessment in this study was stratified random sampling. The number of samples was based on the rule of thumb, where each pixel that had been classified was sampled into at least 50 samples to create an error matrix if the area is less than 1 million acres and the number of classes is less than 12 [15]. However, the number of samples in this study was increased to 150 pixels per class to reduce bias. Error matrix was applied to derive the classification accuracy. The overall accuracy of each land cover classification was above $85 \%$.

\subsection{Identification of urban physical growth types}

The types of urban physical growth in this study were calculated using equations developed by $\mathrm{Xu}$ et al. [4]. The equation is basically developed from the scheme of urban growth patterns proposed by Wilson et al. [3]. This equation has been widely used in several other studies even though they were referred by different terms $[5,6,16,17]$. To get the types of urban physical growth, the built-up area data was converted to vector format and processed by using various tools in ArcGIS 10.4.1. The equation used to quantify urban physical growth types $(S)$ is as follows:

$$
S=\frac{L_{c}}{P}
$$

where, $L c$ is the length of a common edge of the newly grown built-up area patch and the existing built-up area patch, and $P$ is the total perimeter of newly grown builtup area patch. Types of urban physical growth are classified as infilling, edge-expansion, and spontaneous growth if $S \geq 0.5,0<S<0.5$, and $S=0$, respectively (Figure. 2).

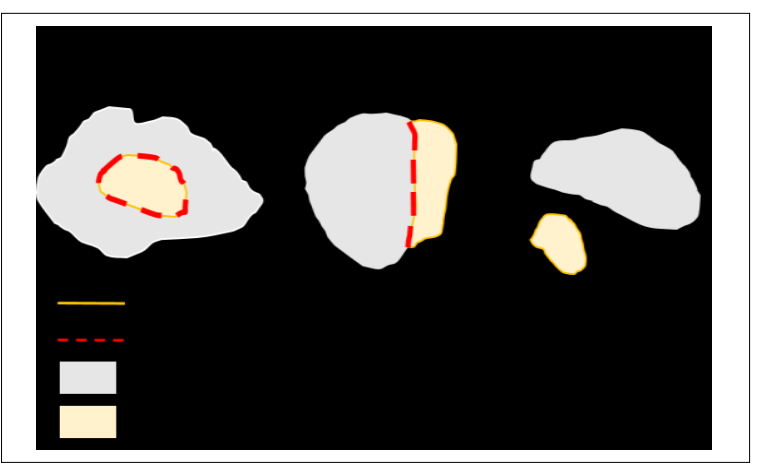

Fig. 2. Illustration of urban physical growth types.
The identification results of urban physical growth patterns can be a reference for reconstructing the urban growth phase [18]. Conceptually, it is preceded by a diffusion phase, in which urban built-up areas are dispersed from an urban core. The next process is characterized by the formation of urban blobs because of the integration of urban patches. This phase is referred to as coalescence, where the dispersed cities turn into more compact forms. Based on this statement, the spontaneous growth reflects the diffusion phase, while the coalescence phase is indicated by infilling or edge-expansion growth [7].

\section{Result and discussion}

\subsection{Built-up area detection from 2005 to 2019}

The spatial distribution and extent of the built-up areas in Banda Aceh City after the 2004 IOT are shown in Figure. 3 and Table 2. Changes in the extent of the builtup area in 2005-2009 and 2009-2019 are significantly different. In general, the increase in the built-up areas had more than doubled in the span of 15 years after the tsunami.

In 2005, the built-up areas in the coastal area were totally destroyed so that the area became open space, especially in Meuraxa and Kuta Raja Sub-districts. The remaining built-up area was 1,426 ha and the distribution was mostly in the central part of the city, specifically in the Baiturrahman Sub-district and Kuta Alam Sub-district. The distributions of built-up areas in Banda Raya, Lueng Bata, and Ulee Kareng Sub-districts were relatively small, although not affected by the 2004 IOT.

Table 2. Extent of built-up area in Banda Aceh City.

\begin{tabular}{|c|c|c|}
\hline Year & $\begin{array}{c}\text { Built-up } \\
\text { Area (Ha) }\end{array}$ & $\begin{array}{c}\text { Proportion } \\
\text { (\%) }\end{array}$ \\
\hline 2005 & 1,426 & 25.67 \\
\hline 2009 & 2,269 & 40.84 \\
\hline 2019 & 3,321 & 59.77 \\
\hline
\end{tabular}

The total built-up area in 2009 was more than 1.5 times the total built-up area in 2005. The area was 2,269 ha and covered $40.84 \%$ of the city area. The new builtup areas mainly expanded to the north and west because of the rebuilding process of the built-up areas that were destroyed by the disaster. Additional new built-up areas had also begun to be identified in areas that were not affected by the tsunami.

Meanwhile, the total built-up area in 2019 is 3,321 ha, where most of the city area has become a developed area with a proportion of $59.77 \%$. The rate of urban physical growth was slowing down. It is clear that the direction of growth had shifted. The new built-up areas were mostly found in the city periphery, especially in Banda Raya Sub-district, Lueng Bata Sub-district, and Ulee Kareng Sub-district. 


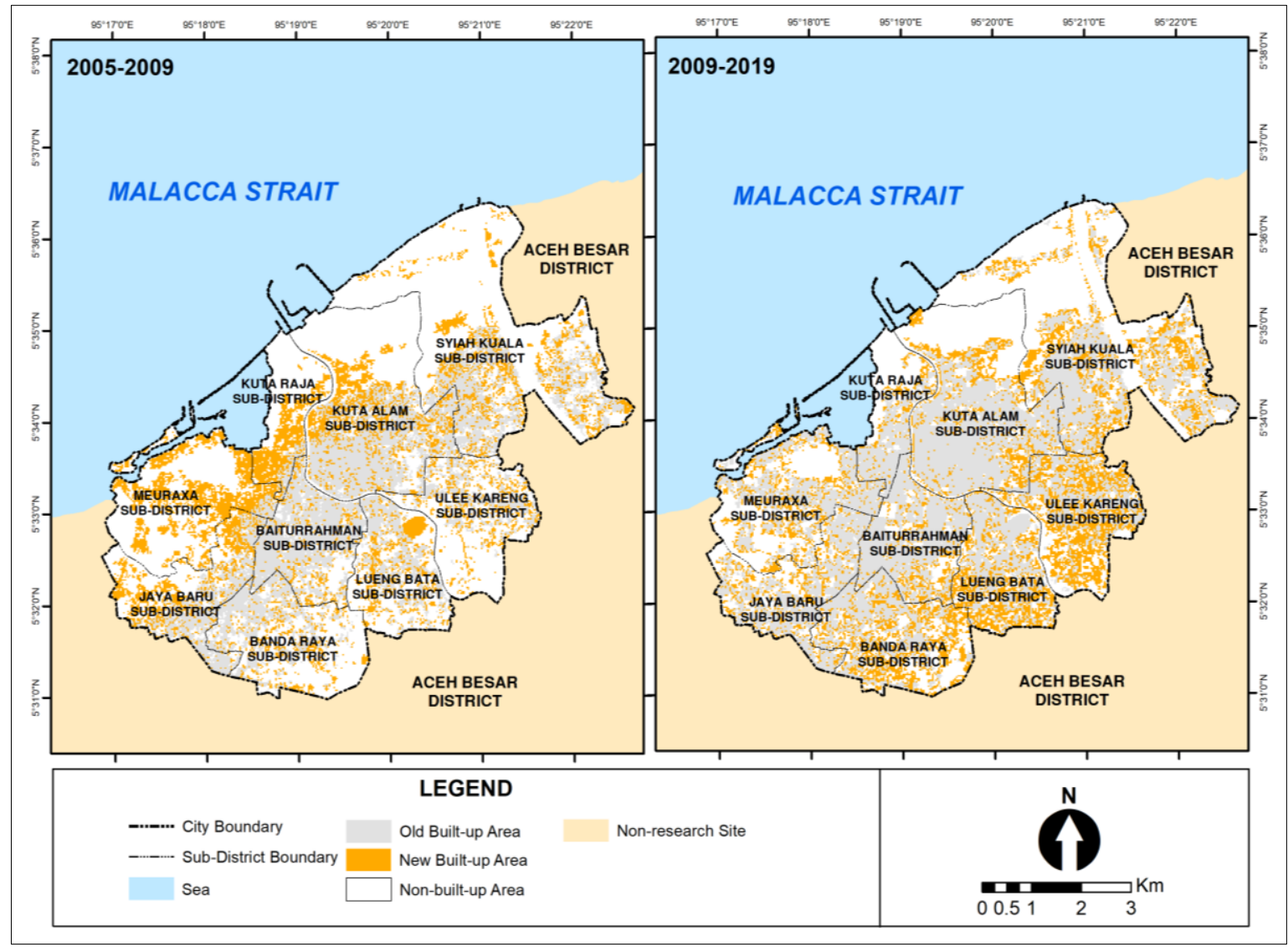

Fig. 3. Built-up area expansion during 2005-2009 and 2009-2019 in Banda Aceh City.

\subsection{Urban physical growth types}

The types of urban physical growth in Banda Aceh City are illustrated in Figure. 4. Three types of growth were identified in the two study periods, both 2005-2009 and 2009-2019, such as infilling, edge-expansion, and spontaneous growth. In general, the results show significantly different urban physical growth patterns in the two periods.

During the urban recovery phase, edge-expansion growth was more dominant in Meuraxa Sub-district and Kuta Raja Sub-district. Infilling growth was predominantly found in the central and eastern parts of the city (especially in Kuta Alam Sub-district and Syiah Kuala Sub-district). In coastal areas, many of the newly built-up areas had expanded sporadically in the form of spontaneous growth. This pattern was also more often found in the suburbs. In the 2009-2019 period, the city had become more compact because the city periphery had begun to be dominated by infilling and edgeexpansion growth. More aggregated patterns were also identified in coastal areas.

The area percentage of urban physical growth types in Banda Aceh City was calculated to obtain detailed multi-temporal patterns. Figure. 5 shows the process of shifting dominance of urban physical growth patterns in the city of Banda Aceh. Edge-expansion was the main type of growth in 2005-2009, while infilling was the main type of growth in 2009-2019. The proportion of spontaneous growth was the lowest in both periods.
Specifically in 2005-2009, these results are consistent with the results of a previous study [12].

The reconstruction and rehabilitation process had an important role in influencing the types of urban physical growth. It can be seen in the dominance of edgeexpansion and infilling growth in the 2005-2009 period, where each had a proportion of $44.19 \%$ and $37.74 \%$. The rebuilding during that period was carried out close to the existing built-up areas that were not destroyed by the 2004 tsunami.

In some parts of the city, the urban development pattern followed the damaged main road network that had been repaired or followed the newly built main road. It is characterized by elongated and linear shapes following the road pattern so as to generate edgeexpansion growth. This is consistent with the research of Sun et al. which stated that edge-expansion growth usually occurs along major transportation routes [5]. Also, the speed of urban physical growth was estimated to have influenced the types of urban physical growth in Banda Aceh City. Yu and Zhou stated that cities with relatively high physical growth rates tend to experience growth with edge-expansion type [19]. This is in accordance with the conditions of urban physical growth in Banda Aceh, wherein the 2005-2009 period, a relatively high growth rate could be seen and the main type of growth was edge-expansion.

The pattern of urban physical growth in the city of Banda Aceh in the 2009-2019 period experienced a change in the dominant type compared to the previous period. The proportion of infilling growth was the most dominant $(52.03 \%)$. Meanwhile, the proportion of the 


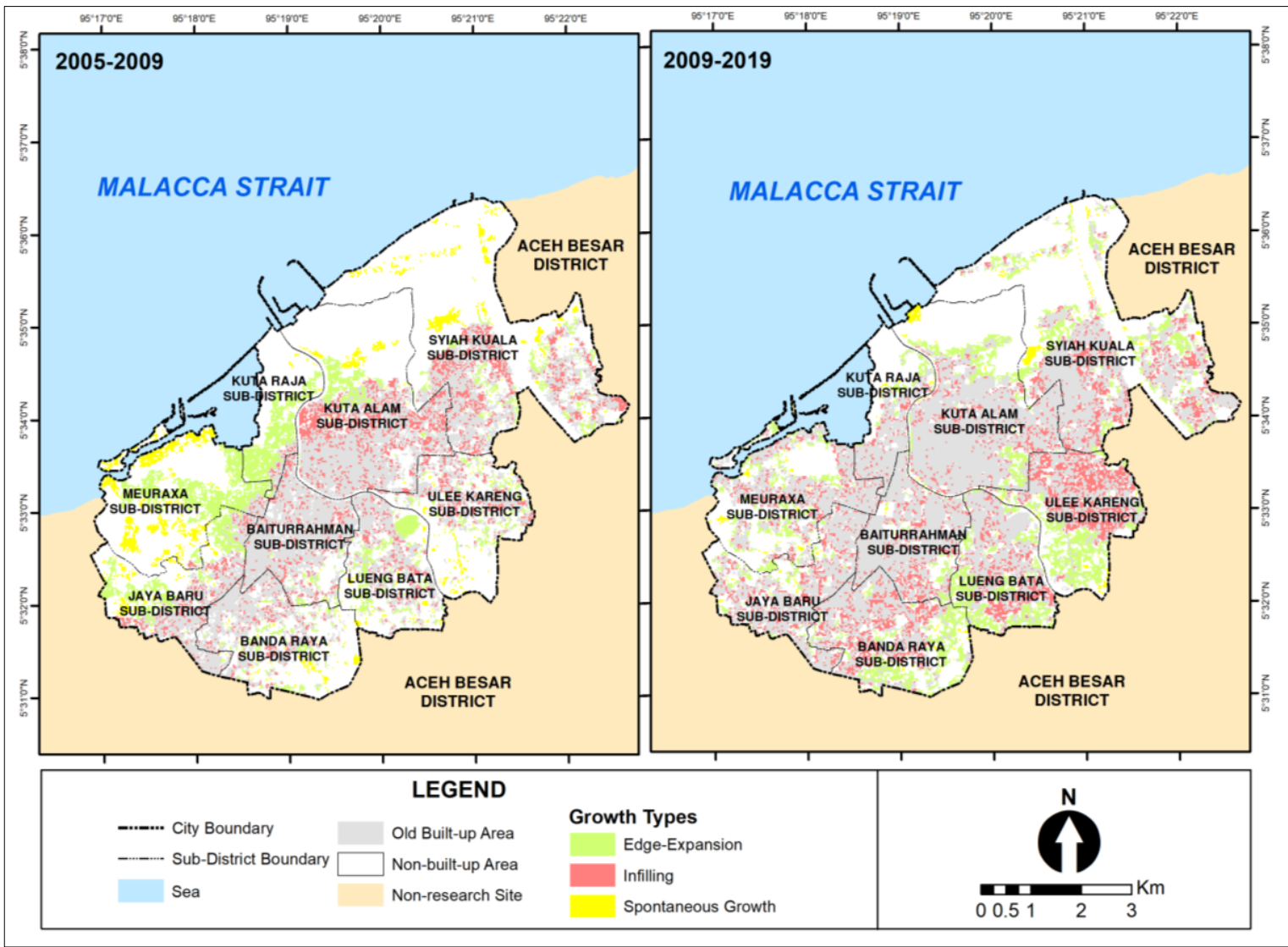

Fig. 4. Map of urban physical growth types in Banda Aceh City.

other two types of growth was $43.71 \%$ for edgeexpansion and $4.26 \%$ for spontaneous growth. This was followed by a decrease in the intensity of growth as the city became more compact. The dominance of this type of growth showed that cities experience physical growth at a stable stage as new built-up areas only develop in open space around the existing built-up areas [5, 19].

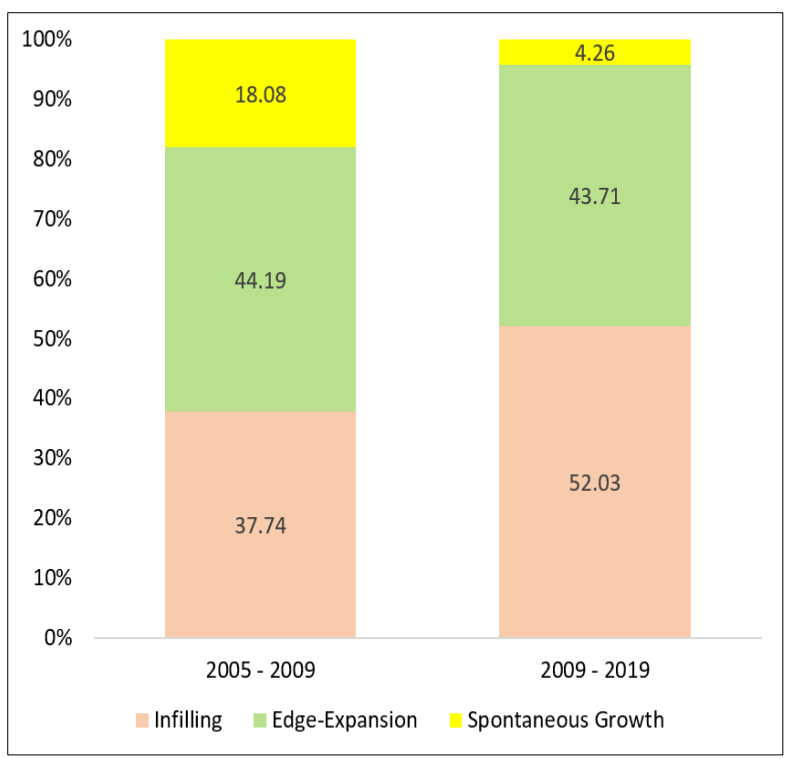

Fig. 5. Graph of area percentage of urban physical growth types in Banda Aceh City.

The process of urban physical growth can be identified from multi-temporal urban physical growth patterns. The process of urban physical growth is characterized by a cycle and oscillation between diffusion and coalescence [18]. The diffusion process was characterized by spontaneous growth type, while the coalescence process was characterized by edgeexpansion growth and infilling. Based on the results of the previous analysis, the main types of urban physical growth in Banda Aceh City were edge-expansion and infilling, both in 2005-2009 and 2009-2019. The proportion of infilling tends to increase, while the proportion of spontaneous growth tends to decrease. In other words, it was an indication that the process of postdisaster urban physical growth in Banda Aceh City coalesced in both periods.

The urban development in Banda Aceh City after the 2004 IOT did not have a diffusion stage even the proportion of the built-up area around $25 \%$. The main factors were that the built-up areas expanded around the main road and the former built-up areas that were affected by the tsunami. These findings differed from other studies in various cities under normal growth conditions. $\mathrm{Xu}$ et al. investigated patterns of urban physical growth in Nanjing, China during 1979-2003 using the same model and successfully proved the hypothesis of a diffusion-coalescence cycle [4]. The same thing was done by Terfa et al. in Addis Ababa and Adama, Ethiopia, where the process of urban physical growth took the form of diffusion-coalescence-diffusion during 1987-2017 [7]. The probability of the city of Banda Aceh undergoing a diffusion stage after 2019 is also very small. It is caused by at least two factors. Firstly, most of the area has been covered by built-up areas. Secondly, the possibility of the emergence of a 
new growth center in the northern part of the city is very small because it is close to a source of tsunami hazard, although the availability of land is still quite high. On a more macro-scale, this city as a whole will become the initial urban core for the next stage of urbanization. Aceh Besar District as a hinterland will experience more intensive urban expansion in the future.

\section{Conclusion}

Urban physical growth was successfully quantified using geographic information systems and remote sensing. The results show that there were changes in the extent of the built-up areas that were relatively fast during 2005-2019 in the city of Banda Aceh. The builtup area increased higher than twofold. The main type of growth during the reconstruction and rehabilitation phase (2005-2009) was edge-expansion (44.19\%). Meanwhile, the main type of growth in 2009-2019 was infilling $(52.03 \%)$. During this period, the city had experienced densification. The percentage of spontaneous growth area was the lowest in both study periods and tended to decrease. Thus, the process of urban physical growth in Banda Aceh City after the 2004 IOT was classified as a coalescence phase along with the dominant types of infilling and edge-expansion growth.

Urban development in the city of Banda Aceh has been at a stable stage along with the compacting of the city. The built-up areas are expected to continue expanding towards the east or south and causing the rapid conversion of green open space. In addition, development in coastal areas must be limited to reduce tsunami risk. Therefore, urban physical growth must be controlled and managed effectively to achieve sustainability.

This paper is a part of the undergraduate thesis conducted by Ikhwan Amri under the guidance of Prof. Sri Rum Giyarsih in the Faculty of Geography, Universitas Gadjah Mada. The authors would like to thank Dr. Djaka Marwasta and Dr. Rini Rachmawati for their meaningful suggestions in improving this research.

\section{References}

1. D. Clark, Urban Geography: An Introduction Guide (Taylor \& Francis, London, 1982)

2. UN, The World's Cities in 2018 - Data Booklet (UN, New York, 2018)
3. E.H. Wilson, J.D. Hurd, D.L. Civco, M.P. Prisloe, C. Arnold, Remote Sens. Environ. 86, 275-285 (2003)

4. C. Xu, M. Liu, C. Zhang, S. An, W. Yu, J.M. Chen, Landscape Ecol. 22, 925-937 (2007)

5. C. Sun, Z.F. Wu, Z.Q. Lv, N. Yao, J.B. Wei, Int. J. Appl. Earth Obs. 21, 409-417 (2013)

6. D.H. Nong, C.A. Lepczyk, T. Miura, J.M. Fox, PLoS One 13, e0196940 (2018)

7. B.K. Terfa, N. Chen, D. Liu, X. Zhang, D. Niyogi, Sustainability 11, 2973 (2019)

8. NGDC/WDS, NCEI/WDS global historical tsunami database, URL: https://www.ngdc.noaa.gov/hazard/tsu db.shtml. (2019)

9. M. Umitsu, C. Tanavud, B. Patanakanog, Mar. Geol. 242, 141-153 (2007)

10. BNPB, Data dan informasi bencana Indonesia, URL: http://dibi.bnpb.go.id/. (2019)

11. BRR, Aceh and Nias One Year After the Tsunami, the Recovery Effort and Way Forward (BRR, Banda Aceh, 2005)

12. A. Achmad, Sirojuzilam, Badaruddin, D.N. Aulia, Int. J. Res. Eng. Technol. 3, 428-435 (2014)

13. BPS Kota Banda Aceh, Kota Banda Aceh Dalam Angka 2020 (BPS Kota Banda Aceh, Banda Aceh, 2020)

14. D. Kushardono, Klasifikasi Digital pada Penginderaan Jauh (Penerbit IPB Press, Bogor, 2017)

15. R.G. Congalton, Remote Sens. Environ. 37, 35-46 (1991)

16. F. Liu, Z. Zhang, X. Wang, Remote Sens. 8, 930 (2016)

17. L. Chen, C. Ren, B. Zhang, Z. Wang, M. Liu, Sustainability 10, 188 (2018)

18. M. Herold, J. Hemphill, C. Dietzel, K.C. Clarke, Remote sensing derived mapping to support urban growth theory, in Proceedings of the ISPRS joint conference 3rd International Symposium Remote Sensing and Data Fusion Over Urban Areas and 5th International Symposium Remote Sensing of Urban Areas, URBAN 2005 \& URS 2005, 14-16 March 2005, Arizona, USA (2005)

19. W. Yu, W. Zhou, Remote Sens. 9, 45 (2017) 